\title{
Performing Reconciliation: Milan and the Memory of Piazza Fontana
}

\section{Elena Caoduro}

Terrorism was arguably the greatest challenge faced by Western Europe in the 1970s with the whole continent shaken by old resentments which turned into violent revolt: Corsican separatists in France, German speaking minorities in Italy’s South Tyrol, and Flemish nationalists in Belgium. Throughout that decade more problematic situations escalated in the Basque Provinces and Northern Ireland, where ETA and the Provisional IRA, as well as the Loyalist paramilitary groups (such as the UVF, and UDA) participated in long armed campaigns. According to Tony Judt, two countries in particular, West Germany and Italy, witnessed a different violent wave, as the radical ideas of 1968 did not harmlessly dissipate, but turned into a 'psychosis of selfjustifying aggression’ (2007, p. 469). In Italy, the period between 1969 and 1983, where political terrorism reached its most violent peak, is often defined as anni di piombo, 'the years of lead'. This idiomatic expression derives from the Italian title given to Margarethe Von Trotta’s Die bleierne Zeit (1981, W. Ger, 106 mins.), also known in the UK as The German Sisters and in the USA as Marianne and Juliane. ${ }^{1}$ Following the film’s Golden Lion award at the 1981 Venice Film Festival, the catchy phrase 'years of lead' entered common language, and is now accepted as a unifying term for the various terrorist phenomena occurred in the long 1970s, both in Italy and West Germany.

By the mid 1980s, however, terrorism had begun to decline in Italy. Although isolated episodes of left-wing violence continued to occur - two governmental consultants were murdered in 1999 and in 2002 respectively - special laws and the reorganisation of anti-terrorist police forces enabled its eradication, as did the 
collaboration of many former radical militants. The anni di piombo or 'years of lead' represent an open question, as well as a wound, in Italian history, given that several episodes of terrorist violence are still without culprits and the requests from the victims have rarely been met by the institutions. The political system did not establish a proper commission for truth and reconciliation, as its primary concern was to promote pacification and individual dissociation from political violence. In recent years a large number of memoirs and fictional works which investigate the political violence of the 1970s have taken up the challenge for dealing with reconciliation as a wider social process and a resolution between antagonistic groups. ${ }^{2}$

The aim of this chapter is to explore how contemporary Italian film and performance arts are changing the post-terrorist memory of Milan during this period. I will begin by describing the historical background and the condition of split memory that especially afflicts public discourse in Italy. In the second part of the chapter, two examples - a fiction film and a performance based on a memoir - are analysed to illustrate the validity of their contribution to understanding reconciliation, and to overcoming trauma. Marco Tullio Giordana’s fiction film, Romanzo di una strage (2012, It., 129 mins, released in the UK and USA as Piazza Fontana: The Italian Conspiracy), and the performance, Spingendo la notte più in là. (Pushing Past the Night, 2008), directed and interpreted by Luca Zingaretti and based on the eponymous book (2009 [2007]) by Mario Calabresi, reconstruct the past through narratives that propose a sharable memory. Focusing on characters and events associated with the massacre of Piazza Fontana in Milan on 12 December 1969, the triggering episode of the 'years of lead', this chapter reveals how the contested and fragmented memory of such an event can be represented, and become effective for promoting dialogue across the political divide. This is not to exaggerate the role played by cultural artefacts, 
films, performances and the visual arts in offering resolution to traumatic events, but it can show how they contribute to the creation of a sharable memory, and assist in a process of reconciliation in the absence of a statutory or official commission.

\section{Historical Background: Italian Terrorisms}

The wide use of the expression 'years of lead', where 'lead' metonymically stands for bullets, might have had the ideological effect of solely denoting left-wing terrorism, whose attacks were characterised by the use of firearms (O’Leary 2010, p. 244). In reality, the terrorist experience in Italy is not limited to left-wing violence alone, but it was a much more complex phenomenon. Historians and social scientists concur that the waves of political violence can be classified into thee main types: attempted military coups d'état (especially since the mid-1960s); paramilitary activities (kidnapping, murders, kneecapping practised by left-wing extremists especially in the second half of the 1970s); and persistent large-scale bombing - a tactic dubbed stragismo, or massacre-ism, which was espoused by neo-fascist organisations with the support of secret services and other international organisations (Lanaro 1992;

Ginsborg 2003; Cento Bull 2007). Citing official figures from the Italian Department of Interior, Alan O’Leary gives account of over 14,000 terrorist attacks, which were committed in Italy in the years between 1969 and 1983 and resulted in 374 deaths and more than 1170 injuries (2010, p. 243).

Generally speaking, the 'years of lead' are considered to have begun on 12 December 1969, when a bomb exploded inside the headquarters of the Banca Nazionale dell’Agricoltura in Piazza Fontana, Milan. The Piazza Fontana massacre (16 dead and 88 injured) has come to stand as the pivotal moment that inaugurated this era, but also stragismo: the indiscriminate massacre by neo-fascist terrorist 
groups, which were facilitated, to a greater or lesser extent by elements of the Italian secret services. This characteristic method of large scale bombing ought to be understood within the political campaign called strategia della tensione, literally ‘strategy of tension’: a grand scheme which aimed to establish a militaristic and authoritarian form of government in Italy by throwing the democratic nation into a state of fear, and making a dictatorial takeover more attractive to the population. Throughout the 1970s bomb attacks continued, reaching their horrific apogee with the bombing at the Bologna rail station on 2 August 1980. ${ }^{3}$ The photographic images of the crater inside the bank in Piazza Fontana and the smashed clock at the station have subsequently become iconic lieux de mémoire of stragismo: sites of memory 'that anchor, condense, and express the exhausted capital of our collective memory' (Nora 1989: p. 24). At the same time, however, social conflicts and paramilitary groups from the left chose to undertake an armed struggle against the state's institutions: targeting judges, politicians, industrialists and journalists. Initially as a reaction to the ‘strategy of tension', politicised former students and workers formed terrorist organisations such as the notorious Brigate Rosse (Red Brigades), which kidnapped and murdered the leading Christian Democrat politician Aldo Moro in 1978.

Two violent episodes are closely connected with the Piazza Fontana bombing and characterise the fragmented memory of the long 1970s. During a routine investigation following the bombing, Giuseppe Pinelli, an anarchist initially suspected of possessing crucial information, died mysteriously, falling from an open window in the police office. Police Commissioner, Luigi Calabresi, who was on duty that night and was collaborating with the investigation of Piazza Fontana, was wrongly accused of Pinelli's death and became victim of a widespread campaign to smear his name. Hundreds of intellectuals, including filmmakers such as Federico Fellini, Bernardo 
Bertolucci and Marco Bellocchio, signed a petition published on the weekly magazine L'Espresso accusing the police officer of being responsible for the death of Pinelli and calling him 'inspector torture' (1971, p. 6). In a climate of heightened political tension, a cell of left-wing militants belonging to Lotta Continua murdered Calabresi outside his home in Milan, in May 1972.

Despite several trials, the last one ending as recently as May 2005, no one has been convicted for the Piazza Fontana massacre; the Court of Cassation, the last court of appeal in the Italian judiciary system, found two neo-fascist terrorists accountable for the attacks but acquitted them on the ground of insufficient evidence. Initially blamed on anarchists, the bomb attack was later linked to the far-right organisation Ordine Nuovo (New Order), since the explosive and timer encouraged the investigators to conclude that neo-fascist individuals were responsible. Nevertheless, all suspects were eventually acquitted and the relatives of the victims had to sustain the legal costs of the trials. Separate hearings revealed, however, that the death of Pinelli was accidental; it was proven that Calabresi was not in the room, but no-one was found accountable for keeping Pinelli in police custody beyond the permitted 48 hours. In 1997, the instigators and perpetrators of Calabresi's assassination were identified and brought to justice, and they were all given long prison sentences after a highly contentious trial.

According to Anna Cento Bull and Philip Cooke the armed struggle has left a lasting legacy in Italy due to 'persistent feelings of mistrust towards the state' for not revealing its concealed support in the attacks, and not convicting the perpetrators of many right-wing massacres remained unaccounted for (2013, p. 102). While some state measures were effective at bringing about the end of organised terrorist groups, such as the pentiti law that afforded reduced sentences to collaborative terrorists, 
others were completely unsuccessful at promoting truth-telling, wider reconciliation and overcoming the trauma. For example, the 'Commissione Parlamentare d'inchiesta sul terrorismo in Italia e sulle cause della mancata individuazione dei responsabili delle stragi' (the Parliamentary Commission on Terrorism in Italy and on the Failed Identification of the Authors of the Massacres) was established on 17 May 1988 but differed fundamentally in its scopes and achievement from the South African model set up in 1993, following the end of Apartheid. ${ }^{4}$ Chaired by Left Democrat senator, Giovanni Pellegrino, the commission failed at investigating puzzling episodes surrounding the bombing massacres and performing a pacifying function between opposing ideological factions. The Parliamentary Commission concluded that a sharable memory of 'the years of lead' was unattainable because of the lack of mutual understanding among the political class and growing feelings of partisanship and revenge between right- and left-wing parties (Fassanella, Pellegrino and Sestieri 2008). The end of the Cold War could have signalled a new phase of relaxation and dialogue between opposing political groups, but state secrets were kept on many puzzling events of the 'years of lead'. ${ }^{5}$ Moreover, the collapse of the old Italian parties (the conservative Christian Democracy, the Socialist and the Communist Parties) ought to have smoothed the way to a reconciliatory and renewal phase in the early 1990s, but, in truth, these events, did not mark a real break in Italian politics. ${ }^{6}$ Old resentments and political sectarianism prevented solidarity and, as a result, several politicians, in particular those belonging to Silvio Berlusconi’s coalition, refused to sign the final report written by chairman Pellegrino. They produced separate concluding statements and put a seal on the commission's reconciliatory work. 
In this post-conflict context, the Italian state has suffered from an emotional illiteracy, characterised by an inability to deal with the pain, anger and frustration of thousands of victims who felt neglected by government policies and institutions. However, the absence of a political will to listen to and to acknowledge the victims' narratives is, however, changing. In 2007 a Parliamentary vote established an Official Day of Remembrance for all the victims of terrorism, which marked a turn towards a more victim-oriented process of reconciliation. During public commemorations, the President of the Republic, Giorgio Napolitano, showed his support to the many families who remained deprived of any truth or justice and urged the political class to clarify the role of state apparatuses in bombing massacres. Nonetheless, these seem to be isolated attempts to propel truth recovery and eventually reconciliation.

\section{Milan as a City of Memory}

This necessary long historical context helps highlight the fragmented complexity of Italian terrorisms. This chapter focuses on Milan, and specifically on the Piazza Fontana massacre and subsequent violent events, and reads them as representative of the torn and 'divided memory' of the 'years of lead' (Foot 2009), whilst the Piazza Fontana massacre exemplified the institutional confusion surrounding the 'strategy of tension'. Several attacks from all fronts of the political divide took place in Milan, totalling 106 casualties and more than 300 injured. These numbers include innocent bystanders caught in the line of fire between police and radicals, victims of neofascist and left-wing violent episodes and victims of state abuse of power. By comparison with other locations the concentration of these shootings, bombings, kneecapping and kidnappings is astonishing. In fact, Milan was, and still is, a crucial industrial, financial and cultural centre, making it the perfect target and arena for opposing groups. Notably, it was the capital of the economic boom in the post-war 
years and the cradle of the television industry (Foot, 2003, p. 9). Industrial cities like Turin and Genoa - and also the more institutional capital of Rome - have witnessed episodes of ferocious violence, given the high presence of trade unions and large Red Brigades cells, but not to the extent of Lombardy’s capital. Even in the cultural imaginary, Milan has a prominent role in the memorialisation of the 'years of lead': the image of a protester with a black balaclava drawing a P38 gun on the riot police was shot in via De Amicis in Milan in 1977 and has become the iconic picture of the armed struggle. Moreover, Milan was the set of many films about terrorism, for instance Marco Bellocchio’s Slap the Monster on Page One/Sbatti il mostro in prima pagina (1972) and Gianni Amelio’s Blow to the Heart/Colpire al cuore (1983).

Analysing the topographic maps of Milan on the website of Vi.Te, one of the major associations for the victims of terrorism in Italy, it is easy to understand the impact of those violent years on the city. As well as collecting, short biographical entries of the victims of terrorism in Milan and the Lombardy region, Vi.Te has started an initiative for a shared memory, creating a webpage that maps every location in Milan, where episodes of left-wing, right-wing or state political violence took place. Most importantly, there are not distinct maps for victims of left-wing or neo-fascist terrorist attacks, but they are grouped according to forms of violence, uniting those that fell or were injured. It also provides a link to Google Maps, where one can observe the present-day locations through Google Street. Their maps become a useful tool to locate the several commemorative plaques, and the gardens and streets titled after casualties of acts of terrorism. In this way, memories are kept alive by reconnecting virtual spaces of commemoration with real locations.

The marble stones that commemorate the sites where Giuseppe Pinelli and Luigi Calabresi died have been at the centre of several controversies, since the 
anarchist rail worker and the policeman are representative victims of opposing ideologies, holding a special place in different sectional memories in Milan, and in Italy as a whole. The public commemorations and tributes to the victims of terrorism have always been a contested space, seeing different constituencies in opposition to each other or against the state. For example, in 2006 the centre-right mayor of Milan allowed the substitution of the marble stone commemorating the anarchist Pinelli, which was placed in a flowerbed of Piazza Fontana by an association of socialist workers and students two years earlier. The removed stone was a copy of an older one, which was laid in 1976 and subsequently damaged by neo-fascist vandals. On the stone sponsored by the city the original epitaph 'killed without guilt' was changed to the less politically-charged 'died innocently', generating public protests and huge debates in the media. At present day, there is no single plaque commemorating the victims of the bombing and the subsequent violent events, but separate stones which reinforce sectarianism between victims. A positive and supportive role to overcome ideological differences has been played by Gemma Calabresi and Licia Pinelli. As Cento Bull and Cooke point out, the two widows met for the first time on 9 May 2009, when the president of the Italian Republic facilitated an encounter during the celebrations of the Day of Remembrance for the victims of massacres and terrorism (2013, p. x). This symbolic meeting, as well as the forthcoming project of the House of Memory in Milan, gives fresh impetus to the possibility of a reconciled memory and puts the city of Milan again at the centre of the debate on political violence, this time, however, as an arena of new reconciliatory dynamics. ${ }^{7}$

In this context, the arts have been at the forefront in establishing a platform for dialogic practices, showing some deliberate attempts to reconcile opposing truths (see Caviglia and Cecchini 2003). One could wonder, however, what kind of 
reconciliation is possible, given that there is no consensus on the nature of Italian terrorisms and no judicial truths about many episodes. Reconciliation is a complex notion, and there are significant disagreements over its definition, scope and application. In his overview of normative accounts of reconciliations in post-conflict societies, Ernesto Verdeja classifies the spectrum of post-violence relations between former enemies in two broad approaches: minimalist and maximalist (2012). According to Verdeja 'minimalist approaches understand reconciliation as simple coexistence, between former enemies, premised on a rejection of violence' (2012, p.168). Minimalist accounts of reconciliation are concerned with pacification, the cessation of violence, rather than mutual forgiveness. The broad debate over political reconciliation in Italy has been framed by this approach; policies focused on reforms of the prison system, the social re-integration of former terrorists and the harmonization of the relationships between the state and political identities (della Porta 1995). For Verdeja, maximalist approaches to reconciliation are characterised, instead, by public recognition and acknowledgment of victims, for instance through reparations. This second approach generates programs that 'call on perpetrators to acknowledge responsibility, repent and ultimately be forgiven by their victims’ (Verdeja, 2012, p. 169). This categorisation seems to underline the partial and incomplete nature of reconciliation after terrorism in Italy, a process which has often left out the victims' needs and wider truth-telling, especially in relation to the bombings.

The following analysis of Piazza Fontana: The Italian Conspiracy and Pushing Past the Night brings further attention to the necessity of including new actors in the process of reconciliation and will illuminate different strategies for dealing with Italy’s violent past. Giordana's film espouses a controversial thesis that 
there is a historical truth behind the 1969 bombing massacre in Milan and in doing so, it foresees reconciliation only if everyone admits their own guilt. The performance (and the original memoir upon which it is based) ultimately demonstrate that the fear that forgiving always mean forgetting might be eliminated.

\section{Conspirational Reconciliation in Cinematic Milan}

In Piazza Fontana: The Italian Conspiracy filmmaker Marco Tullio Giordana - and his long-time collaborators, the scriptwriters Stefano Rulli and Sandro Petraglia - set out to uncover judicial intrigues and political machinations lurking behind the unsolved bombing in Milan. Although no fiction film until recently has addressed this episode, the massacre has often been touched upon in historical dramas, as a key background episode, the trigger of the armed struggle. It is, for example, mentioned in films such as Michele Placido’s Romanzo Criminale (2005) and Renato De Maria’s Front Line/ Prima Linea (2009), the latter, set in the periphery of Milan, traces the radicalization of a whole generation back to Piazza Fontana. ${ }^{8}$

As the first historical feature film to examine the episode, the film was bound to spark great interest as well as controversy, given that it benefited from state aid and had secured European funding for its international distribution. Similar to the debates provoked by Dario Fo’s farcical play Accidental Death of an Anarchist/ Morte accidentale di un anarchico (1970) - a drama about the death of Pinelli in the aftermath of the Piazza Fontana massacre - Giordana’s film created a media frenzy in Italy because of the conspirational explanation for the bombing (see Peruzzo 2012). This excitement, however, was more subdued outside Italy, where foreign audiences found it difficult to follow the plot and the various characters. Despite being considered a difficult export outside of festivals and specialist audiences Piazza 
Fontana: The Italian Conspiracy won the Special Jury Prize at the 2012 Karlovy Vary International Film Festival and was screened in France, Germany, the UK, and North America enjoying moderate success for a European film (Young 2012).

Piazza Fontana: The Italian Conspiracy offers a convoluted cinematic tale rich in Machiavellian complexities - that even native Italians would have trouble keeping straight. With a didactic tone, signalled by the subdivision into thematic chapters, the film is a loose adaptation of Il segreto di Piazza Fontana (2009), a controversial book by investigative journalist Paolo Cucchiarelli. The book argues that there were, in fact, two bombs planted in the bank: a small demonstrative device placed by the anarchists and a deadly one assembled by neo-fascist individuals with the help of elements within the secret services. This bizarre theory, rebutted by the dismissal of a new inquiry in September 2013, offers an explanation for the English title of the film, The Italian Conspiracy. However, this translation goes against the slogan chosen for the Italian marketing of the film, 'tutta la verità' (the whole truth), contradicting the presumed intention of the filmmaker: providing the mere facts, the true story of the event. Giordana's ambition to reveal the perpetrators and instigators of the terrorist attack alludes to the aims of Pier Paolo Pasolini's newspaper article, ‘Cos’è questo colpo di stato? Io so’ (What is this coup d’état? I know), which first appeared in Corriere della Sera on 14 November 1974 (2007, pp. 88-93). The article represents a vigorous 'j'accuse’ against the Italian state for failing to identify the offenders and for its own implication behind bomb attacks in the early 1970s.

The conspiracy theory that the film embraces has a dual function: firstly, it exposes connivances between the police, the army, the secret services, foreign forces, such as NATO officials, and terrorist groups. Through its investigative work behind large quantities of official documents, the film substitutes the ineffectual 
parliamentary truth commission in acknowledging the culpability of elements of the state. Secondly, by sharing the guilt among all parties, this interpretation of the massacre produces a pacifying function, as both sides of the political divide participated in the shame of the terrorist attack. No one is found guilty, because everyone is. The State knew and looked away, the anarchists placed a device and the fascists did that as well, apparently on the same day at the same time. As a result, the Piazza Fontana massacre appears as an inevitable product of its time more than a planned attack. The only certainty emerging from the film is the acknowledgement of the profound difficulty in reaching a historical truth and the necessity for a process of truth-telling as the main goal of reconciliation. Giordana gives voice to the relatives of the victims of Piazza Fontana who demand to know the identity of the perpetrators as a precondition for reconciliation and eventually forgiveness.

The Italian Conspiracy adopts a conventional visual style, depicting the climate of social unrest through a washed out palette, long shadows and austere set design. It is interesting to note that the city of Milan did not finance the production, allowing only the shooting of the first nocturnal sequence. Instead, the municipality of Turin and the Piedmont Film Commission offered locations and funding for the shooting. The reconstructed depiction of Milan shown in the film is grim; the city appears divided between antagonising forces and in stark contrast with the sunny - if enigmatic - Rome, where all political decisions are made. For example, during the scene of Pinelli's funeral in Milan's monumental cemetery the camera pans from the army, the journalists observing from afar and the anarchists reinforcing the idea of a community split in different constituencies. The cityscape is especially relevant: external shots of fascist architecture, such as the tribunal and the police headquarters, allude to a sense of oppression and control signified by these buildings. 
The only unifying force is the representation of the victims. Black and white archival footage show the state funeral for the victims of the massacre; an undistinguishable mass is assembled outside Milan's cathedral, and aerial shots give the impression of a city united in mourning. Operatic music, in this case Mozart's Requiem Mass, highlights the severity of the moment, but the deliberate choice of the movement 'Lacrimosa dies illa' emphasises once again the failure of the Italian justice to condemn the perpetrators (the chorus sings in Latin: full of tears shall be that day/On which from ashes shall arise/The guilty man to be judged).

Although the film is dedicated to the victims of the bombing in Piazza Fontana, it prefers to focus on two illustrious casualties of the power struggles between ideologies that followed: police commissioner Luigi Calabresi (Valerio Mastrandrea) and the anarchist railworker Giuseppe Pinelli (Pierfrancesco Favino). The choice of the actors is quite interesting: on the one hand, the charisma and international appeal of Favino were deemed suitable to convey the magnetism and physical presence of the railworker. On the other hand, the choice of Mastrandea, who is known for his liberal points of view and non-conformist roles, might have finessed some aspects of the firm but righteous policeman. Pinelli and Calabresi are shown as even being on amicable terms with one another despite the different political positions. Their tragic fate is preceded by similar scenes of tranquil family life; Mrs Pinelli wraps her husband with a light grey scarf, whilst Mrs Calabresi offers hers a white tie, two gestures which allude to an emotional farewell. In the film, their deaths are transfigured by collective martyrdom and foreshadow that of Aldo Moro, the most notorious victim of the 'years of lead' who was kidnapped and murdered by the Red Brigades in 1978 (O’Leary 2013). This association is clearly made in the film as the sequences set in Rome shows the future president of the Christian Democrats acting 
as Minister of Foreign Affairs; the link is further stressed by mentioning the Moro assassination at the end of the film. By associating these casualties with Aldo Moro, the film elevates Pinelli and Calabresi to public recognition as innocent victims of political violence.

Nevertheless, the films does not take a position about the death of the two main characters, which, in fact, occur off-screen; the mysterious demise of Giangiacomo Feltrinelli, the book publisher and revolutionary follows a similar pattern. This is indicative of not only neglecting conventional dramatic thriller tropes, but most importantly, avoiding the legacy of those events. Calabresi's family, for instance, criticized the filmmaker for downplaying the tense climate preceding the murder of the police commissioner. Giordana does not show any courage in attacking a part of the left-wing intellectuals who contributed to fomenting false accusations against Calabresi. This choice could be considered an alibi, a cautious and conservative decision to not explore the downfall into armed struggle of 'erring comrades' and the initial tacit consent of violent methods by left-wing sympathisers.

Piazza Fontana: The Italian Conspiracy is praiseworthy as a first attempt to narrate the violent events occurred in Milan at the turn of the 1970s. While it avoids the previous antagonism between victims, it does represent a premature memory or cinematic commemoration still intertwined with conspiracies. In fact, the explanation of the two bombs, only recently debunked, seems only to achieve a tolerable coexistence of erstwhile enemies, without any common ground. Pushing Past the Night shows a different approach to aiming at overcoming the trauma of the 'years of lead' through a profound social transformation. 


\section{Coming to Terms with the Past: a Son's Memoir}

In 2007, Mario Calabresi, son of Police Commissioner Luigi, published a memoir, recounting the dramatic experience of his family and other victims of terrorism. On 6 December 2008 an adapted version of Pushing Past the Night was performed on the stage of the Auditorium Parco della Musica in Rome under the direction of Luca Zingaretti. The impact of the show was so significant that a recording was broadcast on RAI 3 in May 2009, on the occasion of the Remembrance Day for all the victims of terrorism, and the same day when the wives of Calabresi and Pinelli met for the first time.

In the style of a civic oration, four actors read extracts from Calabresi's memoir, offering to the audience a restructured and reduced version of the themes addressed in the book. Specifically, the performance deals with the placid family life and the politically-heated climate preceding the policeman's murder, the mourning process of the family, issues encountered by relatives of victims of terrorism and a final reflection on amnesty, forgiveness and reconciliation. The extracts are accompanied by piano music and intercut by black and white archival images of the 'years of lead', including the same images of the funeral for the victims of Piazza Fontana present in Giordana's The Italian Conspiracy. The hour-long performance is never too detached; it is at the same time emotional and absorbing with personal anecdotes, such as the recollections of the Calabresis' brothers in keeping their father's memory alive. Amateur films of holidays on the mountains and coloured photographs from the private collection of the Calabresis' are projected on the background. By including these images, the performance successfully counters the 
customary narrative of the 'years of lead', shifting the focus from the experience of the perpetrators to the victims and their families.

Zingaretti's production is austere: all actors wear black costumes, the stage is practically empty and low-lit until the final monologue, chairs and lecterns are the only props used. It is a sometimes disorienting production, since it shifts back and forth in time in order to convey a personal struggle to come to terms with the death of a father - Mario was two years old in 1972 - the trials against the terrorists and the long indifference, or inadequacy of the Italian state. Pushing Past the Night illuminates the journey of a victim's family toward closure, while at the same time, explaining episodes of Italian history and the national failure to come to terms with the 'years of lead'. The ultimate aim of the performance is making visible the fallacies of a society which is not yet fully reconciled with its violent past.

Pushing Past the Night sketches a theory of political reconciliation based on what Verdeja defines as 'mutual respect', suggesting a scenario where former enemies declare their faith in the future of a relationship (2009). Anger is not what prevails in the text. Indeed, it is perhaps in the transcendence of anger that this performance is most unforgettable. In his memoir, Calabresi goes beyond hatred and seems to indicate the path towards reconciliation, by firstly avoiding the polarization 'right-left', still present in many films about terrorism. Examples include feature films such as Daniele Lucchetti's My Brother is an Only Child/Mio fratello è figlio unico (2007), where the national struggle mirrors the duality between a communist elder brother turned terrorist and a neo-fascist younger one. Calabresi underlines that within his family, feelings of hate never developed towards the figure of Pinelli: 'in our family, Pinelli was never considered an enemy’ (Calabresi, 2009, p. 50). 
Furthermore, Calabresi indicates two offensive practices which have been impeding the process of 'moving on': the media's clemency towards former terrorists and the state's carelessness towards the relatives of the victims. Calabresi, now editor in chief of a major Italian newspaper, suggests that reconciliation is possible if society avoids the perils of the current romanticisation of radical militants and the transformation of former terrorists into media personalities. The voices of terrorists, from all factions, has widely dictated the relationship between memory, history and historiography (Lanslots and van den Bogaert 2009). Specifically, Calabresi's discussion of how many former terrorists became acclaimed intellectuals and political figures, while serving little to no time in prison for their crimes, depicts the chaos and inadequacy of the Italian justice system, as well as one of the major causes of resentment in the victims.

Equally troubling is the issues of the state's responsibility and carelessness, especially towards victims who were employed by the state. For instance, Calabresi acknowledges the importance of public recognition, both material and symbolic, given to victims who died in service, but denounces years of neglect by the state in favour of practices that facilitated the rehabilitation of terrorists. In her overview of victim-centric narratives in postmillennial public discourse in Italy, Ruth Glynn correctly concludes that survivors and relatives of the victims are 'doubly burden': by their own personal healing process, but also by the task of facilitating a broader societal healing (2013, p. 285).

Calabresi seems to be torn between the pragmatic requirements of reconciliation, the return to normalcy, and a vision of pure forgiveness, here intended as an exceptional and extraordinary act. In the final part of the memoir, and the 
performance, he compromises for a more normative understanding of forgiveness and thus reconciliation. His interpretation of reconciliation contemplates one of the risks outlined by Verdaja, that the emphasis on transformation through forgiveness might become coercive (2012, p. 169). When writing about the Italian government's failure to inform his family that one of his father's murderers was released from prison, Calabresi affirms:

I don't think the government should be required to seek victims' permission before passing laws or deciding whether to grand a pardon, parole, early release or supervised furloughs. Such matters should be carried out in the general interest, which might not coincide with the interests of the families of the victims. [...] the pain of private citizens should obviously not be an impediment (2009, p. 66).

This formulation problematically defends the state's role in dictating forgiveness, leaving victims with little opportunity to oppose it. Nonetheless, he embraces the transformative powers of this approach. In grasping this lesson at the end of an arduous and personal odyssey, Calabresi creates a new continuity between past, present and future, by disposing of all newspaper clippings about his father kept in a suitcase and substituting them with holiday pictures (Lanlots and Bogaert, 2009, p. 6). In fact he justifies his choice by writing: 'in order to turn page respecting the memory, I had to place my bets on love and life' (Calabresi, 2009, p.121). From this perspective, the work of mourning translates into a pacified separation between agent and act, creating a space for reconciliation.

Pushing Past the Night represents a positive contribution to counter narratives about the 'years of lead' offered by former terrorists and as such, it challenges Italy's 
approach to reconciliation by focusing on institutional and media failings and their impact on public opinion. This is an example which consigns the experience of terrorism to history, discussing it with more serenity and cancelling the distinction between right-wing and left-wing victimhood, thus endorsing tolerance of others. However, it represents a still tentative attempt, using Paul Ricoeur's words 'a wish in the optative mood' (2004, p. 456), since it displays on-going tensions and areas where much cultural work remains to be done.

\section{Conclusions}

The memories of the 'years of lead' have long remained unresolved. Historically divided societies - such as Italy - cannot be reconcile on the shaky ground of divided memories; memory being culture, it would thus result in a divided identity. Collective traumas, such as the Piazza Fontana massacre, an act of terrorism, which still remains enveloped in mystery, represent an open wound for the city of Milan, and also for the whole country. Given that the perpetrators of the Piazza Fontana bombing remain unknown, reconciliation in Milan crucially still needs the right conditions for its realisation: historical truth and justice. Thus, establishing whether reconciliation has occurred in post-terrorist Italy is surprisingly difficult. While studies of political science and sociological research can offer valuable insights into overall patterns, this chapter proposes a different perspective to access the process: some success has indeed been achieved in cultural artefacts.

Piazza Fontana: the Italian Conspiracy and Pushing Past the Night are at the forefront of new discourses about political violence, pushing for a wider truth-telling process and a victim-inclusive approach. Former terrorists' accounts, both factual and fictional, became self-referential and fuelled stereotypical accounts of the 'years of 
lead'. These two examples are instead part of a peace-building process between constituencies in order to balance the relationship between perpetrators, victims and the state.

The two texts explored in this chapter then raise questions about a viable approach of reconciliation, one that take seriously the role of the victims, while also being a normalising and socially acceptable approach. Giordana’s film plays a part in the provision of a sharable memory, denouncing violent forms of violence and connivances between terrorists and elements of the state, but understands reconciliation as tolerable coexistence. The conspiracy theory of the two bombs in Piazza Fontana goes beyond logical explanation and reflects the desire for order and understanding of mysterious events. As suggested by Calabresi in his memoir, once truth is established, the only way for healing is in a balanced dialogical approach: victims and perpetrators. In his words: 'one fundamental point is that reconciliation is important and possible but cannot be based on an unbalanced accounting of Italy's years of terrorism’ (2009, p. 90). In fact, whilst state’s interventions drew particularly strong criticism from the victim’s groups, they were effective in pacifying Italian society by putting politics before justice or truth, leaving some issues unresolved. Recognising victims and their narrative is, however, equally important.

An honest history of the 'years of lead' is necessary, though this can be painful for the relatives of the victims and unsettling for those who took the defence of the perpetrators. The efforts of the last decade, commemorative plaques, stamps, Day of Remembrance and artistic works, are a sign that Milan is working together for new shared interests. 


\section{Notes}

[1] The German Sisters is more than a tragic story about a sisterly relationship, as the English-language titles seem to allude to. Based on Christiane and Gudrun Ensslin's lives, the latter was one of the founders of the terrorist group Rote Armee Fraktion (Red Army Faction, RAF), the film contextualises the origin of West German terrorism by recounting the political awakening of two women in the late 1970s. The strict Protestant upbringing, the silence about their parents’ relationship with the Nazi party and the horrific images of concentration camps and massacres in Vietnam prompt Marianne to become an underground terrorist and Juliane, a feminist activist. In an interview Von Trotta clarifies that the title, literally 'the leaden time', does not directly hint at the violence that erupted in West Germany as a consequence of the students protests in 1968, but it refers to the gloomy atmosphere of the 1950s, when discussions about the German responsibility and guilt for the Holocaust were silenced (Di Caprio 1984, p. 56).

[2] One of the first attempts to provide a complex dialogical exchange between victims and perpetrators is the fictional film La seconda volta (The Second Time, Mimmo Calopresti, 1996, It., 80 mns.), which recounts the encounter between a university professor and the former terrorist who shot at him. Notable examples which proffer a victim-oriented process to reconciliation include the documentaries:

Giovanna Gagliardo’s Vittime (Victims - The Years of Lead, 2008, It., 95 mns.) and Luigi Maria Perrotti’s L'infame e suo fratello (The Infamous and His Brother, 2008, It., 92 mns.).

[3] A time-bomb exploded in the waiting room of the Central Station in Bologna, killing 85 people and wounding more than 200. Two neo-fascist terrorists were 
sentenced to life imprisonment for executing the attack, whereas three secret services officers were condemned to shorter sentences for investigation diversion.

[4] The Commissione stragi was established as a cross-party forum, and was expected to complete its investigations in eighteen months. Largely reformed in 1996, it extinguished its function in March 2001. The conclusions of the various reports do not hold any power of action, hence distinguishing the Italian version from other genuine commissions. The documents can be consulted at http://www.parlamento.it/parlam/bicam/terror/home.htm\#1 [accessed 30 July 2014]. [5] Terrorism in Italy could also be considered as the by-product of the Cold War and specifically the result of the intervention of foreign forces. Within the strategy of opposing spheres, the left-wing terrorist groups were considered friends rather than enemies by Moscow, and they were paid or facilitated on the principle of destabilising Western democracies. Neo-fascist activities were monitored and allowed by NATO to maintain Italy’s under its influence and prevent a turn to the left.

[6] The investigations of a pool of young judges in Milan uncovered large-scale corruption in public life. The subsequent scandal (Tangentopoli, literally Kickback City) led to the collapse of the political system: a whole political class came under attack and the major parties in Parliament were dissolved (see Gundle and Parker 1996).

[7] The City of Milan has finally decided to create a public space for the remembrance of all victims of political violence, from the Resistance war (1943-45), to the 'years of lead' and the mafia massacres. Works for a museum and a congress and cultural centre will be completed in late 2014 (Stella 2013). 
[8] The latest fictional work dedicated to the investigations of the Piazza Fontana massacre is the episode "Il Commissario" (The Police Commissioner), part of the TV series The Broken Years/Gli anni spezzati (Graziano Diana, 2014). Specifically the TV drama focuses on the vicissitudes of Luigi Calabresi and the Milan investigative pool from the perspective of a young policeman.

\section{Reference List}

Gli anni spezzati (The Broken Years), 2014. [DVD] Directed by Graziano Diana. Italy: Albatross Entertainment Spa and Rai Fiction, 600 min.

Die bleierne Zeit (The German Sisters), 1981. [DVD] Directed by Margarethe von Trotta. West Germany: Bioskop Film and SFB.

Calabresi, M. 2009 [2007]. Pushing Past the Night: Coming to Terms with Italy’s Terrorist Past. Translated from Italian by Michael F. Moore. Pittsfield, NH: Other Press.

Cento Bull, A. 2007. Italian Neofascism: The Strategy of Tension and the Politics of Nonreconciliation. Oxford: Berghan.

Cento Bull, A. and Cooke, P. 2013. Ending Terrorism in Italy. London and New York: Routledge.

Colpire al cuore (Blow to the Heart), 1983. [DVD] Directed by Gianni Amelio. Italy: Antea Cinematografica, 105 min.

Cucchiarelli, P. 2012. Il segreto di Piazza Fontana. Milan: Ponte alle Grazie. 
Della Porta, D. 1995. Social Movements, Political Violence and the State. Cambridge: Cambridge University Press.

Di Caprio, L. 1984. 'Baader-Meinhof Fictionalized’. Jump Cut, 29, pp. 56-9.

L’Espresso. 1971. 'Manifesto contro il commissario Calabresi' (editorial), L'Espresso, 27 June, p. 6.

Fassanella G., Pellegrino G. and Sestieri C. 2008. Segreto di Stato. Verità e Riconciliazione sugli anni di piombo. Milan: Sperling \& Kupfer.

Fo, D. 1970. Morte accidentale di un anarchico. Turin: Einaudi.

Foot, J. 2003. Milano dopo il miracolo. Biografia di una città. Milan: Mondadori.

— 2009. Italy’s Divided Memory. Basingstoke, Hampshire: Palgrave-Macmillan.

Glynn, R. 2013. 'The “Turn to the Victim” in Italian Culture: Victim-centred

Narratives of the anni di piombo’. Modern Italy, 18, pp. 373-90.

Ginsborg, P. 2003. A History of Contemporary Italy: Society and Politics 1943-1988. London: Palgrave-Macmillan.

Gundle, S. and S. Parker, eds. 1996. The New Italian Republic: From the Fall of the Berlin Wall to Berlusconi. London: Routledge.

L'infame e suo fratello (The Infamous and His Brother). 2008. [DVD] Directed by Luigi Maria Perotti. Italy-Germany: Stamen Film Srl and White Balance. 92 min. Judt, T., 2007. Postwar: A History of Europe since 1945. London: Pimlico.

Lanaro, S. 1992. Storia dell'Italia repubblicana: dalla fine della guerra agli anni novanta. Venice: Marsilio. 
Langlots, I. and van den Bogaert, A. 2009. 'Spingendo la notte più in là. Il discorso della memoria.’ In: Colloque Littérature et “temps des révoltes” (Italie, 1967-1980) Lyon, [online] 27-29 November. Available at http://colloque-temps-revoltes.enslyon.fr/spip.php?article132\#acte [accessed 15 July 2014].

Mio fratello è figlio unico (My Brother Is an Only Child). 2007. [DVD] Directed by Daniele Lucchetti. Italy: Cattleya, Babe Film, 108 min.

Nora, Pierre. 1989. 'Between Memory and History: Les Lieux de Mémoire’. Representations, 26 (Spring), pp. 7-24.

O’Leary, A. 2010. 'Italian Cinema and the "Anni di Piombo”. Journal of European Studies, 40 (3), 243-57.

— 2013. 'Introduction to Romanzo di Una Strage'. Italian Cinemas/Italian Histories, [blog] 19 August. Available at http://italiancinema-

mumbai.tumblr.com/post/58502045763/introduction-to-romanzo-di-una-strage [Accessed 3 August 2014].

Pasolini, P. 2007 [1975]. Scritti Corsari. Milan: Garzanti.

Peruzzo, M. 2012 'Romanzo di una strage, persi nel labirinto’. Frasisfatte, [blog] 26 April. Available at http://frasisfatte.wordpress.com/2012/04/26/romanzo-di-unastrage-persi-nel-labirinto/ [Accessed 5 August 2014].

Prima Linea (The Front Line). 2009. [DVD] Directed by Renato De Maria. Italy: Lucky Red, Radio Télévision Belge Francophone, 100 min.

Ricoeur, P. 2004. History Memory and Forgetting. Chicago: Chicago University Press. 
Romanzo criminale. 2005. [DVD] Directed by Michele Placido. Italy: Cattleya, Babe Film and Warner Bros, 152 min.

Romanzo di una strage (Piazza Fontana: The Italian Conspiracy). 2012. [DVD]

Directed by Marco Tullio Giordana. Italy: Catleya, Babe Film and Rai Cinema, 129 $\min$.

Sbatti il mostro in prima pagina (Slap the Monster on Page One). 1972. [VHS]

Directed by Marco Bellocchio. Italy: Jupiter Internazionale and UTI Produzioni, 93 $\min$.

La seconda volta (The Second Time). 1995. [DVD] Directed by Mimmo Calopresti. Italy: Ban Film, La Sept Cinéma and Sacher Film, 80 min.

Stella, A. 2013. 'Nasce la casa della Memoria. Sarà pronta il 25 aprile 2015’. Il Corriere delle Sera, [online] 2 September. Available at http://milano.corriere.it/milano/notizie/cronaca/13_settembre_2/nasce-casa-memoriaanpi-aned-stragi-terrorismo-partigiani-2222862141519.shtml [Accessed 3 August 2014].

Verdeja, E. 2009. Unchopping a Tree: Reconciliation in the Aftermath of Political Violence. Philadelphia, PA: Temple University Press.

— 2012. ‘The Elements of Political Reconciliation'. In: A. Keller Hirsch, ed. Theorizing Post-conflict Reconciliation. London and New York: Routledge. pp. 16781.

Vi.Te. 2013. La casa della memoria di Milano delle vittime del terrorismo e dello stragismo in regione Lombardia. [online] Available at http://www.casamemoriamilano.org/index.html [Accessed 5 August 2014]. 
Vittime - Gli 'Anni di piombo’ (Victims). 2009. [DVD] Directed by Giovanna Gagliardo. Italy: Rai Cinema and Offside, 95 min Young, D. 2012. “Story of a Massacre: A Review’. The Hollywood Reporter. [online] 30 March 2012. Available at http://www.hollywoodreporter.com/review/story-amassacre-film-review-306441 [Accessed 5 August 2014]. 